\title{
Eusideroxylon zwageri (Ulin) as Key Species in Two Zones of Sangkima Rain Forest, Kutai National Park, East Kalimantan
}

\author{
Jehan R. Haryati ${ }^{*}$, Intan N. Azizah ${ }^{2}$ and E. Arisoesilaningsih ${ }^{1}$ \\ ${ }^{1}$ Biology Department, Mathematic and Natural Sciences Faculty, Brawijaya University, Malang, Indonesia \\ ${ }^{2}$ Kutai National Park, East Kalimantan, Indonesia
}

\begin{abstract}
Aim of this research was to study trees' diversity quality in primary and intensively used forest of Sangkima area in Kutai National Park (TNK), East Kalimantan (Borneo). Field observation was carried out by vegetation analysis using 17 sampling plots of $25 \times 25 \mathrm{~m}^{2}$. Community structure of each forest was determined by calculating trees' density, basal area, frequency, important value and stratification of species. While trees diversity was estimated by taxa richness, Shannon-Wiener diversity index, and rate of endemism. Both forests were compared by Morisita community similarity index. Data were tabulated by Microsoft Excel 2007 and statistically analyzed by PCA method and supported by hierarchical cluster analysis in SPSS 15.00 for windows. The result showed that diversity quality in primary and intensively used forest of Sangkima TNK was high, indicated by similar stratification. The forests were composed by A stratum trees of $>30 \mathrm{~m}$ high to ground cover plants, but they were dominated by B stratum trees of $20-30 \mathrm{~m}$ high. Primary forest's formation was Eusideroxylon zwageriMixed Dipterocarpaceae, while intensively used forest's formation was E. zwageri. Taxa richness of both forests was not different significantly. In the primary forest was found 34 species, 25 families and 16 orders, while intensively used forest was found 36 species, 20 families and 13 orders. Diversity Index of primary forest $(\mathrm{H}=4.57)$ was slightly higher than secondary forest $(\mathrm{H}=4.28)$. Rate of endemism of both forests reached $100 \%$. Eusideroxylon zwageri and Cananga odorata were co-dominant in the Borneo rain forest. Tree of E. zwageri showed a biggest trunk and largest canopy. Cananga odorata showed a high density in both zones. Luxurious jungle performed A to E strata, but B stratum was dominant. Based on those five characters, trees' diversity quality in Sangkima was still high. Bi plot analysis showed that trees' community structure of both forests composed by three groups. In secondary forest, E. zwageri was a key species and characterized by high important value, while species C. odorata, Dyospiros borneensis and Dillenia beccariana found in a high distribution, otherwise other trees were classified into the $3^{\text {rd }}$ group. Comparing to the secondary forest, even though E. zwageri was also as dominant tree, but the virgin one showed more species growing in a better density, distribution and dominance.
\end{abstract}

Keywords: Tree, Borneo, rain forest, community structure, quality diversity, Kutai National Park

\section{INTRODUCTION}

Kutai National Park (TNK) is one of representation of lowland tropical rainforest in East Kalimantan. Ulin-meranti-kapur forest, mixed Dipterocarpaceae, mangrove and kerangas were some vegetation formation in TNK. TNK

\footnotetext{
*Corresponding address:

Jehan R. Haryati

Biology Department, Brawijaya University

Jl. Veteran, Malang 65145,

East Java, Indonesia

Email : jhn_hryti@yahoo.co.id
}

is consist of core, primary, intensively used, rehabilitation and buffer zones [1]. Natural forest was the highest carbon storage compared to agriculture landscape caused by its high trees' diversity with plenty of ground plants and manures [5]. Ecosystem service is the ability of ecosystem to directly or indirectly profit human's efforts, such as maintain hydrology cycle, climate regulation, water and air purgation, maintain atmosphere composition, pollination, soil formation and storage and nutrition cycle [6]

Aim of this research was to study trees' diversity quality in primary and intensively used forest of Sangkima area in TNK, East Kalimantan (Borneo). Database of trees' 
diversity are expected as consideration of next related environmental research and policy, especially efforts to overcome global warming such as reforestation, environmental education, wildlife conservation and green accounting.

\section{Study Site}

Geographically Sangkima Natural Resort was at $0^{\circ} 7^{\prime} 54^{\prime \prime}-0^{\circ} 33^{\prime} 53^{\prime \prime} \mathrm{S}$ and 116 $6^{\circ} 58^{\prime} 48^{\prime \prime}$ $117^{\circ} 35^{\prime} 29^{\prime \prime}$ E [9]. Common topography is lowland and flat and steep hills in height of 70 $200 \mathrm{~m}$ asl [4]. Sangkima has tropical climate with average precipitation $1.543 \mathrm{~mm}$ per year and average temperature are $27^{\circ}-33^{\circ} \mathrm{C}$. Sangkima's total width \pm 61.641 ha or $31 \%$ of all 198.629 ha TNK coverage. Majority of Sangkima is formed by Dipterocarpaceae forests and it is home for many of faunas [9].

\section{MATERIALS AND METHOD}

Field observation was carried out by vegetation analysis using nine (for intensively used forest) and eight (for primary forest) sampling plots of $25 \times 25 \mathrm{~m}^{2}$ (for trees with $\mathrm{DBH}$ $\geq 20 \mathrm{~cm}$ ). Trees diversity was estimated by taxa richness, Shannon-Wiener diversity index and rate of endemism. Rate of endemism determined based on comparison of endemic species' density to all species' density. Endemism status determined based on literature of Malesia phytoregion.

Community structure of each zone was determined by calculating trees' density, basal area, frequency (and its relative value), important value and stratification of species. Observation on trees' stratification was descriptively analyzed related to its vertical spaces utilization [11]. Both forests were compared by Morisita community similarity index [3]. Data were tabulated by Microsoft Excel 2007 and statistically analyzed with PCA method and supported by hierarchical cluster analysis in SPSS 15.00 for windows to display the plot relationship between objects (trees) and sites based on its variables (trees' density, basal area, frequency and important value).

\section{RESULTS AND DISCUSSIONS Community Structure}

Sort of species with the 10 highest important values in each forest showed that Eusideroxylon zwageri (ulin) and Cananga odorata dominated present in both forests. It was a possibility of $c 0$ dominant between them in Sangkima tropical rainforest. Species E. awageri had a big trunk and large canopy due to its highest important value in both forests. A large canopy also showed by Koompasia excelsa in primary forest despite of $E$. zwageri. The highest density showed by E. zwageri which was presented in all sampling plots of intensively used forest as much as 26 individu and $56 \%$ sampling plots of primary forest (5 of 8 ) as much as 13 individu. It showed high distribution of E. zwageri in both forests (Fig.1). These were caused by purposely design of $E$. zwageri in secondary forest [12]. Ulin forest is one specific type of Kalimantan forest [7].

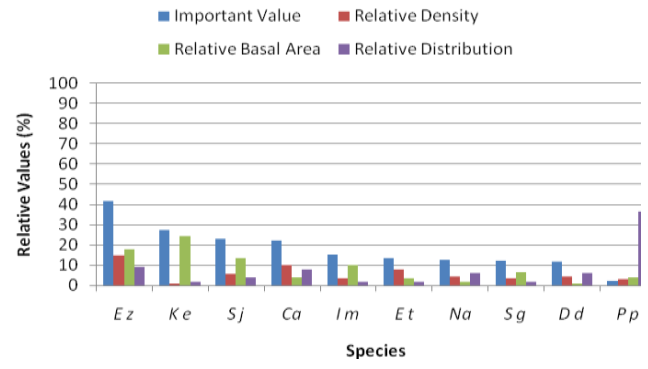

(a)

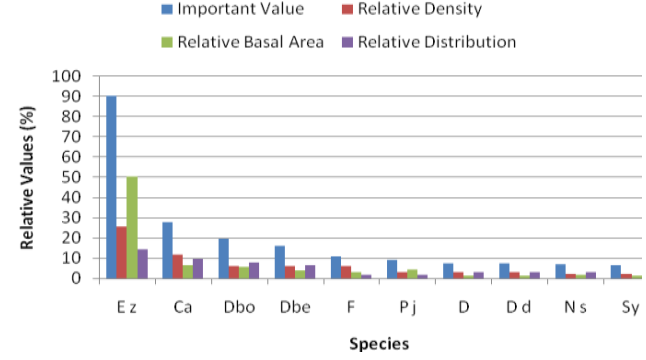

(b)

\begin{tabular}{|c|c|c|c|c|c|}
\hline \multicolumn{6}{|c|}{ Description: } \\
\hline$E_{z}$ & : Eusideroxylon zpwageri & $\mathrm{Ca}$ & : Cananga odorata & $D b o$ & : Diospyros borneensis \\
\hline Dbe & : Dillenia beccariana & $F$ & : Ficus sp. & $P j$ & : Pterospermum javanicum \\
\hline$D$ & : Diospyros sp. & $D d$ & : Dracontomelon dao & Ns & : Nauclea subdita \\
\hline Sy & : Syzigium sp. & $\mathrm{Ke}$ & : Koompasia excels & sj & : Shorea joborensis \\
\hline Im & : Irvingia malayana & Et & : Elmerillia tsiampaca & $\mathrm{Na}$ & : Nauclea sp. \\
\hline Sg & : Shorea gratissima & $P p$ & : Pometia pinnata & & \\
\hline
\end{tabular}

Figure 1 Density, Basal Area and Distribution of 10 Species with Highest Important Value in Intensively Used (a) and Primary (b) Forest 
Luxurious jungle performed A to E strata in both forest. Shorea in height of \pm 30 dominated the hilly primary forest, while flatter area was a mixed Dipterocarpacae forest. Overall formation of primary forest is mixed Dipterocarpacae - Eusideroxylon zwageri forest. Below A stratum, continued canopy of B stratum was dominant. Similar to primary, intensively used forest also has A-E stratum, although domination of A stratum was E. zwageri (ulin) wich is the key species of natural forest of Kalimantan [10]. Formation of secondary forest is E. zwageri. Ferns and trees' offspring covered ground surface layer. B stratum was dominant in both forest.

Morisita community similarity index based on trees' density showed that both zones have similar trees' density $\left(C_{M}=0,80\right)$. The reason were both zones stood close together and they were included as one zone before. Both forests have similar composition of trees' species density. On the contrary, Morisita community similarity index based on important value and relative basal area showed that they were different community ( $C_{M}$ of important value $=$ 0,64 and $C_{M}$ of relative basal area $\left.=0,04\right)$. The differences presumably caused by human intervention in changing complexity and regeneration of trees' vegetation in intensively used forest.

\section{Trees' Diversity}

Taxa richness of intensively used forest is 36 species which is concluded in 20 family and 13 order. Annonaceae was the most family found concluded in Magnoliales order. Primary forest has 34 species which concluded in 25 families and 16 orders. Dipterocarpaceae as dominant family in this primary forest concluded in Theales order and the second dominant order is Magnoliales. Both Taxa richness in both forest was not significantly different (Fig. 2). But primary forest showed more complex taxa richness than intensively used one, in family and order number even intensively used forest has more species.

Diversity index of primary forest $(\mathrm{H}=4.57)$ was higher than intensively used one $(\mathrm{H}=4.28)$ caused by its taxa richness' complexity and density in each sampling plot. High taxa richness in family-order rates and density proportion of each tree species for each zone gave a high diversity index. Diversity index of primary forest in Sangkima was higher than diversity index of primary forest in Barito Ulu, Middle Kalimantan, which was dominated by Dipterocarpacecae, i.e. 4,17 [2]. Both forest showed high quality diversity of natural vegetation forest, indicated by high rate of endemism that is $100 \%$. No exotic species found in both zones. It means quality of ecological services in both zones reached maximum value as nature forest [8].

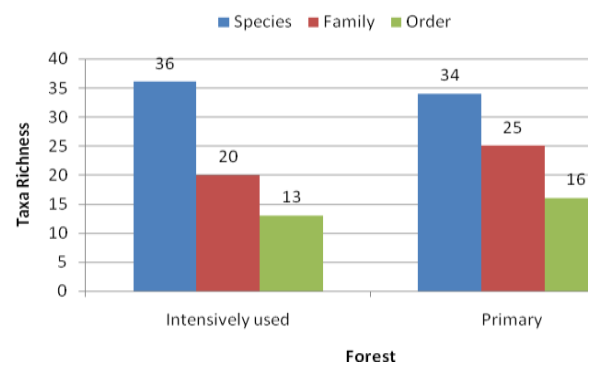

Figure 2 Trees' Taxa Richness in Intensively Used and Primary Forest

Table 3 Trees' Diversity Quality and Community Structure in Both Zones

\begin{tabular}{l|l|l}
\hline \multicolumn{1}{c|}{ Variables } & \multicolumn{1}{|c}{ Primary Zone } & $\begin{array}{l}\text { Intensively } \\
\text { Used Zone }\end{array}$ \\
\hline Stratification & A-E & A-E \\
\hline Formation & $\begin{array}{l}\text { Eusideroxylon zwageri } \\
\text { - Dipterocarpaceae } \\
\text { Campuran }\end{array}$ & $\begin{array}{l}\text { Eusideroxylon } \\
\text { zwageri }\end{array}$ \\
\hline Density (ind.ha-1) & 88 & 102 \\
\hline Basal area (cm $\left.{ }^{3}\right)$ & 229292,88 & 162255,47 \\
\hline Frequency (\%) & 6,18 & 7,00 \\
\hline Taxa richness: & 34 & 36 \\
Species & 25 & 20 \\
Family & 16 & 13 \\
Order & 4,57 & 4,28 \\
\hline Diversity Index & 100 & 100 \\
\hline Rate of Endemism & & \\
(\%) & & \\
\hline
\end{tabular}

\section{Bi plot Analysis}

Bi plot analysis (Fig. 3) showed that tree community structures of both forests were composed by three groups (supported by hierarchical cluster analysis in SPSS). In secondary forest, E. zwageri was a key species and characterized by high important value, while species C. odorata, Dyospiros borneensis and Dillenia beccariana found in a high distribution, otherwise other trees were classified into the $3^{\text {rd }}$ group. Comparing to the secondary forest, even though E. zwageri was also as dominant tree, but the virgin one showed more species growing in a better density, distribution and dominance. 


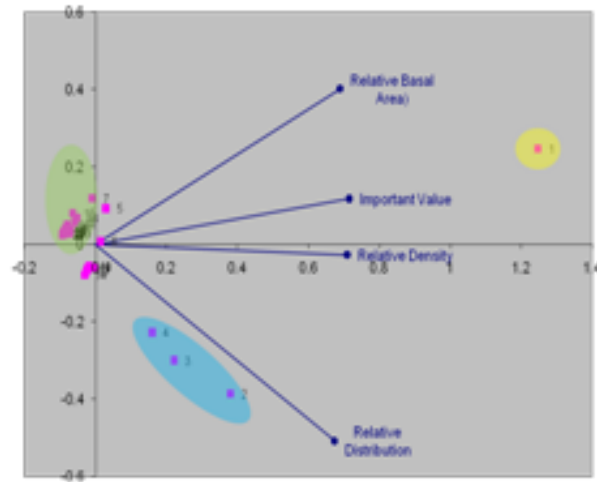

(a)

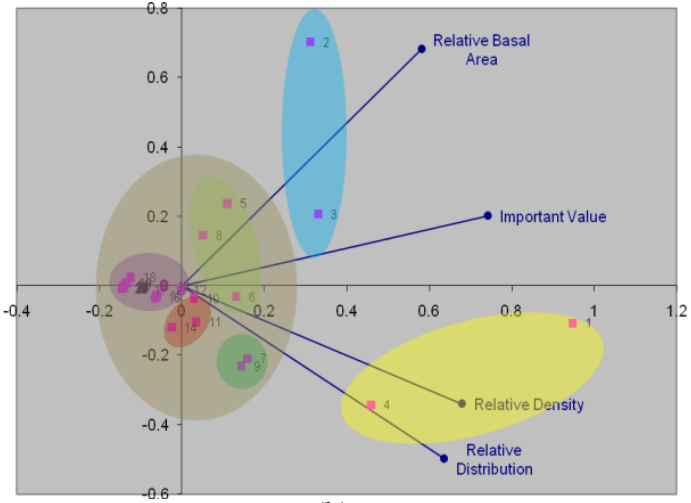

(b)

Figure 3 Bi plot Analysis in Intensively Used (a) and Primary (b) Forest

\section{CONCLUSIONS}

Primary and secondary forest of Sangkima showed a high trees diversity, richness, stratification and rate of endemism. Based on those characters, trees' diversity quality in Sangkima was still high. Taxa richness of both forests was not significantly different, but primary forest has higher diversity and more complex.

\section{ACKNOWLEDGMENTS}

We would like to express a sincerely gratitude to Kutai National Park for supporting and facilitating this study. Sincerely thanks were also conveyed to those who help us a lot in the fields.

\section{REFERENCES}

[1] Balai TNK, Taman Nasional Kutai : Pesona Hutan Hujan Tropis Dataran Rendah Kalimantan Timur, Balai Taman Nasional Kutai, Bontang, 2007.

[2] Brearly FQ, Prajadinata S, Kidd PS, Proctor J, and Suriantata, Abstract : Structure and Floristics of an Old Secondary Rain Forest in Central Kalimantan, Indonesia, and a Comparison With Adjacent Primary Forest. Forest Ecology and Management 2004, 195 (3), 385-397.

[3] Cox TF and Cox, A General Weighted Two-Way Dissimilarity Coefficient, Journal of Classification 2002, 17, 101-121.

[4] Departemen Kehutanan Taman Nasional Kutai, http://www.ditjenphka.go.id/index. $\mathrm{php} ? \mathrm{a}=\mathrm{kn} \& \mathrm{~s}=\mathrm{k} \& \mathrm{i}=28$.
[5] Hairiah K and Rahayu S, Pengukuran 'Karbon Tersimpan' di Berbagai Macam Penggunaan Lahan, Bogor, World Agroforestry Centre - ICRAF, SEA Regional Office, University of Brawijaya, Indonesia, 2007, 77.

[6] Hooper DU, Chapin S, Ewel J, Hector A, Inchausti P, Lavorel S, Lawton JH, Lodge DM, Loreau M, Naeem S, Schmid B, Setala H, Symstad AJ, Vandermeer J and Wardle DA, Effects of Biodiversity on Ecosystem Functioning: A Consensus of Current Knowledge, Ecological Monographs 2005, 75(1), 3-35.

[7] MacKinnon K, Hatta G, Halim H and Mangalik A, Seri Ekologi Indonesia, Buku III : Ekologi Kalimantan. Prenhallindo. Jakarta, 2000.

[8] Pagiola S, Agostini P, Gobbi J, de Haan C, Ibrahim M, Murgueitio E, Ramírez E, Rosales M, Ruíz JP, Paying for Biodiversity Conservation Services in Agricultural Landscapes. Environment Department Paper 2004, 96.

[9] Sari N, The Opportunity of Enhancing Ecoturism Businesses in Sangkima Ecoturism Area, Kutai National Park, J. Analisis Kebijakan Kehutanan 2008, 5 (3), 153 - 164.

[10] Simbolon H, Dinamika Hutan Dipterocarp Campuran Wanariset Semboja, Kalimantan Timur Setelah Tiga Kali Kebakaran Tahun 1980-2003, Biodiversitas 2005, 6 (2), 133-137.

[11] Soerianegara I and Indrawan A, Ekosistem Hutan Indonesia. Laboratorium Ekologi Hutan, Fakultas Kehutanan IPB. Bogor, 2005.

[12] Taman Nasional Kutai, Balai, Taman Nasional Kutai: Pesona Hutan Hujan Tropis Dataran Rendah Kalimantan Timur, Balai Taman Nasional Kutai. Bontang, 2007. 